\title{
Zoo story
}

Alastair Hay looks at the London Zoo, now experiencing some changes at the top

\begin{abstract}
$A^{T}$ its Annual General Meeting this week, the Zoological Society of London (ZSL) was due to witness a major change in the composition of the Council, its governing body. Both the President, Prince Philip, and the Secretary, Lord Zuckerman, were resigning their offices, with Prince Philip leaving the Council altogether. The Council nominated Lord Zuckerman as President and Dr Ronald Hedley, the Director of the British Museum (Natural History), for the Secretaryship. The Secretary of the ZSL is the executive officer of the Council; when it was a salaried post in the years 1847-1943 it was one of the most sought-after positions by zoologists in Britain.
\end{abstract}

Three years after its inception in 1826 -under the auspices of Sir Stamford Raffles (the first President) and the then President of the Royal Society Sir Humphrey Davy-the ZSL was incorporated by Royal Charter with the specific objects of "ensuring the advancement of zoology and animal physiology and the introduction of new and curious subjects of the animal kingdom". Animal physiology at this time was concerned primarily with the optimal conditions for animal breeding. Thus, whereas Raffles was more interested in the scientific potential of the Zoo, Davy-in Raffles' view-was more concerned with its "practical and immediate utility to the country gentlemen".

Davy's ideas notwithstanding, his support enabled the ZSL to develop rapidly into the centre for zoological discussion in Britain. In previous years the Linnean Society had been the hub of these discussions, although it was principally concerned with botany. There is some irony in the fact that the foundation of the ZSL was a reaction against this bias; the Linnean's own development, in 1788 to cultivate "the science of natural history in all its branches", was itself a reaction to the Royal Society's own preoccupation with the physical sciences.

During its first hundred years the ZSL's publications were mainly concerned with systematics, comparative anatomy, taxonomy and phylogeny. In this respect they very much reflected the interest of the Secretaries of the Society, men such as Philip Lutley Sclater (1859-1902) and Peter Chalmers Mitchell (1902-1935). But well before Sclater retired, the biological sciences were themselves undergoing rapid change. Zoology and animal phy- siology were now sciences which required animal experimentation and a knowledge of genetics, biochemistry and endocrinology. The Establishment at the Zoo seemed to be unaware of these developments and consequently younger zoologists were looking elsewhere. The Society was losing the scientific support on which its integrity and very survival depended.

\section{Huxley's problems}

Julian Huxley was the first of the experimental zoologists to be appointed Secretary. Although he attempted to change the Society's approach to zoology he was, in the main, unsuccessful. By 1942 Huxley and the council were openly opposed to one another. Huxley resigned in 1943, an action which was regarded by many zoologists as a serious defeat for progressive scientists. For the next twelve years few changes were possible in the Society. The situation for the duration of the war and the first decade of postwar Britain required Huxley's successors, Sheffield Neave and Lord Chaplin, to devote all available resources to restoration following bombdamage and to the replenishment of the animal collections. Lord Zuckerman became Secretary in 1955 with the ZSL in a very poor state.

The ZSL received confirmation of its status as an educational charity in 1930. Lord Zuckerman believes implicitly in the importance of the Zoo as an educational institution and in the need for the Society to adhere to the terms of its Charter and his determination to institute changes along these lines and to bring it back into the mainstream of zoology involved him in a major clash with Fellows of the Society in 1957. At the Annual General Meeting that year he proposed, on behalf of the Council, an increase in Fellows' subscriptions (unchanged for over 100 years), the creation of a new class of Scientific Fellow, and the extension of public visiting hours on Sundays.

The changes were essential if the Society was to preserve its charitable status and to increase its revenue. For many of the Fellows, however, these proposals represented a considerable challenge to their privileged status. As a result the 1957 meeting was probably one of the most lively in the Society's history. The Council's proposals were finally ratified, but not before the dispute was dragged into the High Court and finally settled in
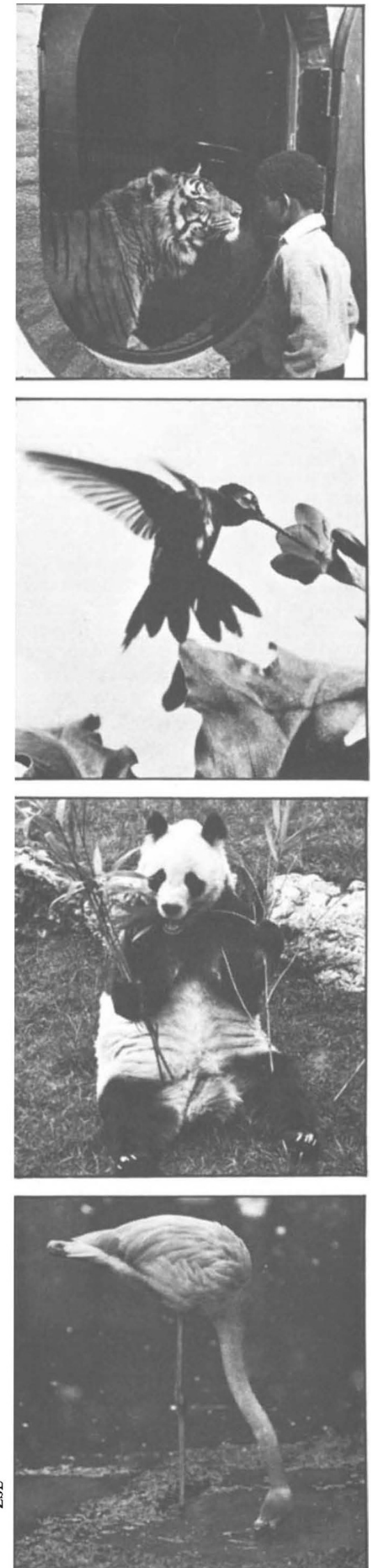

Zoo guests 
the Court of Appeal. The proposals and court ruling were incorporated in a new Royal Charter in 1963.

Ivor Montagu, one of the ZSL's Vice-Presidents and a regular visitor to the Zoo for nearly seventy years, believes that the 1957 proposals were absolutely essential for the Zoo's survival. In his view the strength of the institution lies in its Charter but the composition of the Council has sometimes made it vulnerable. He says it was set up in a way which grew alien to the world around it: the Zoo in its early days was very much a preserve of the gentry; a walk in the Zoological Gardens on Sundays by the Fellows and their friends was very much 'the thing to do'. The First World War altered the social climate and this, he says, forced the Fellows to relinquish some of their privileges. By pushing the 1957 proposals through, he argues, Lord Zuckerman "rescued the Zoo and brought it into the modern world." For many years London Zoo had indulged in the policy of 'stamp-collecting'-it had to have at least one specimen of each species. But with greater concern about conservation and the alteration in public attitudes that policy changed. The emphasis is now placed on maintaining fewer varieties of animals and these in viable breeding colonies.

\section{Zoo activities}

The ZSL is an institution which maintains the national collection of animals. It owns one of the most comprehensive zoological libraries in the world and is responsible for an extensive educational scheme which catered for 53,000 pupils in 1976. The Society publishes more scientific journals than even the Royal Society and

As of this week Lord Zuckerman will preside over all the Zoo's affairs and chair any of its meetings which he attends. Previously, as the Zoo's Secretary, he had a more demanding task, which is one obvious reason why he might retire from the post. But, though now 73 , he will still be around to offer advice, just as he has done in another capacity, that of a government science adviser. This link has lasted for the best part of 40 years, and culminated in promotion to Chief Scientific Adviser from 1964 to 1971 . He is still to be found in and around the corridors of power.

Interviewed last week, Lord Zuckerman responded firmly to the suggestion that with the explosion of information no single individual could possibly advise over the whole spectrum of science. What was wanted of a scientific adviser, he argued, was an understanding of the "political, national and international" implications of technical decisions taken by governments; the immense political implications of President Carter's decision not to proceed with the breeder reactor, for example. That a political sense was required was particularly true in addition it runs two research institutes of world renown. These activities, undertaken in addition to the normal display of animals, are financed in the main by gate proceeds. The ZSL's 1976 Annual Report states that with a turnover of some $£ 2.5$ million and a combined attendance of close on $2 \frac{1}{4}$ million at Regent's Park and Whipsnade, the Society had a year-on surplus of $£ 179,000$. But this sum, unfortunately, will have to be used to pay off the deficits accumulated in 1974 and 1975 when the effects of inflation and recession were sorely felt.

The additional activities undertaken by the ZSL are an obvious strain on the Society's revenue. Both in Britain and abroad many other institutions with far fewer responsibilities are in receipt of regular government subventions. London Zoo is not so endowed. The obvious question is whether it should be. Lord Zuckerman is circumspect with his answer. All he says is that the ZSL is as worthy of support as many of the institutions in regular receipt of public funds.

An intense debate is being conducted at the moment by the staff within zoos to decide their real purpose-the educational function of zoos, their role in conservation of endangered animal species, the nature of scientific research to be carried out and so on. The 1976 Report acknowledges part of that discussion. With its facilities the Society is well placed to become "an international centre for the scientific study of the problems of conservation." The Council proposes to combine the two research institutes, the animal hospital and pathology laboratory into an integrated 'Institute of Zoology'. The scientific expertise and support of the

when all government departments already had specialist technical committees to consider long term planning decisions. Zuckerman says that "the idea of appointing a scientist just because he is a Nobel Laureate who has unravelled the structure of some particularly heavy protein molecule is nonsense. The idea of having the best mathematician is nonsense"

It needs no mathematician to calculate that Britain's Research Councils are now having a comparatively lean time. Zuckerman acknowledges that in the $1950 \mathrm{~s}$ and $1960 \mathrm{~s}$ he was one of the individuals who convinced people that science should be supported in a much bigger way and that now people have the right to enquire after the results of that policy. With the golden age of expansion over, some scientists will draw little comfort from his belief that they will just have to accept the cuts as a fact of life in a country as "hard-up" as Britain. But he believes the current period of belt-tightening will not restrict "real creative thought", and that there will be no long-term repercussions for scientific output. new institute in reproductive physiology, biochemistry, immunology, radiology, parasitology and genetics "can put real knowledge behind attempts to breed stocks of rare animals". This is to become one of the institute's main projects.

Finance for conservation research, however, is very difficult to find. Many zoologists feel that at least some of the money raised for wildlife preservation generally could be used more profitably for the scientific research needed to back up the conservation programme. One organisation concerned with conservation is the World Wildlife Fund. Its Vice-President and Founder Chairman, Sir Peter Scott, feels that conservation is important in the context of zoos. He says zoos are especially important in two respects: for the captive breeding of species threatened by extinction, and for education. Zoos have a great responsibility to educate the young, he argues, and the ZSL has done well in both areas; although the Fund did not at the moment finance any conservation research at London Zoo, if a good case was made they "would consider supporting it".

The ZSL's total income in 1829 was about $£ 12,000$. Some $16 \%$ of this was spent on scientific activities. Today the proportion of income spent on research, publications and education stands at the respectable level of $18 \%$.

\section{Hedley's task}

Ronald Hedley, the man succeeding Lord Zuckermann as Secretary of the ZSL, is a biologist by training with a background in chemistry, zoology, geology and physiology. His experience at the Natural History Museum should equip him well to deal with the public and with the scientific and educational functions of the Zoo; last week he said he was looking forward to the prospect of working with new colleagues there. But he is not approaching his new job with any preconceived ideas. Believing in the need to sample opinion, of which there will be no shortage at the Zoo, he intends to have a period of consultation first.

The Council of the ZSL has the ultimate responsibility for ensuring that the Society is successful. Dr Hedley as a member of that Council now has the two-fold task of involvement in the running of the Zoo and the Natural History Museum, which is an essentially complementary institution. $\mathrm{He}$ is conscious that the goodwill and support of their staff is essential for their continuing success, and takes up his post when the Zoological Society of London is probably more confident about its future than at any time in the past fifty years. 